\title{
Hut lung: a domestically acquired pneumoconiosis of mixed aetiology in rural
} women

\author{
J P Grobbelaar, E D Bateman
}

\section{Abstract}

A form of pneumoconiosis in rural African women termed "Transkei silicosis" has been thought to be due to silica particles inhaled while they are hand grinding maize between rocks. Twenty five women were studied who were considered to have this condition according to the following criteria: rural domicile, radiographic and lung biopsy evidence of pneumoconiosis, no exposure to mining or industry and no evidence of active tuberculosis. They were assessed for radiological, pathological, physiological and bronchoalveolar lavage fluid features. Potential aetiological factors were assessed by determining levels of exposure to respirable quartz and non-quartz containing dusts and smoke in rural dwellings during maize grinding and cooking. Most of the women were symptomless. Radiological findings ranged from a miliary pattern to extensive fibrosis resembling progressive massive fibrosis. Histological features included simple "anthracosis" in 12, anthracosis with macules in six, and mixed dust fibrosis in seven. Cell numbers and their proportions in lavage fluid were normal. More than $60 \%$ of macrophages were heavily laden with inorganic inclusions. Respirable quartz concentrations and calculated cumulative time weighted exposures were below those recommended for industry during grinding with sandstone $(100 \%$ quartz) and they were even lower during grinding with dolerite containing no quartz despite the presence of an appreciable amount of quartz in the ground maize. Total respirable dust and smoke concentrations were greater than the recommended safe levels. Three women had no exposure to maize grinding. It is concluded that the inhalation of nonquartz containing dust and smoke from biomass fuelled fires is more important in the aetiology of this condition than exposure to quartz dust. The term "hut lung" may be more appropriate.

Medicine Univers of Cape Town and Groote Schuur Hospital, Observatory 7925, Cape Town, South Africa J P Grobbelaar E D Bateman

E D Bateman Professor Bateman

Accepted 15 February 1991

Domestically acquired pneumoconiosis has been described in women from the Transkei district of South Africa. ${ }^{1}$ In their original paper Palmer and Daynes suggested that the term Transkei silicosis should be used for this condition as the chest radiographic features were similar to those of silicosis in other settings, postmortem reports on two patients who died from respiratory failure confirmed features of silicoanthracosis, and analysis of maize meal ground according to traditional methods between rocks containing quartz showed particles of quartz and small amounts of silicates. A chest radiographic survey of 152 healthy nurses in Transkei hospitals identified 11 cases in $1967(7 \cdot 2 \%){ }^{1}$ In 1972 chest radiographic changes observed during a survey of patterns of disease suggested a lower incidence-namely $0.3 \%$ of adult women. ${ }^{2}$ Maize grinding was implicated by these authors because this activity is performed daily for 30-90 minutes by girls and women over the age of 9 years, so that by the fifth decade, when most cases are discovered, there has been lengthy exposure ${ }^{1}$ (fig 1). On the basis of this evidence a preventive programme was launched to encourage the use of hand or

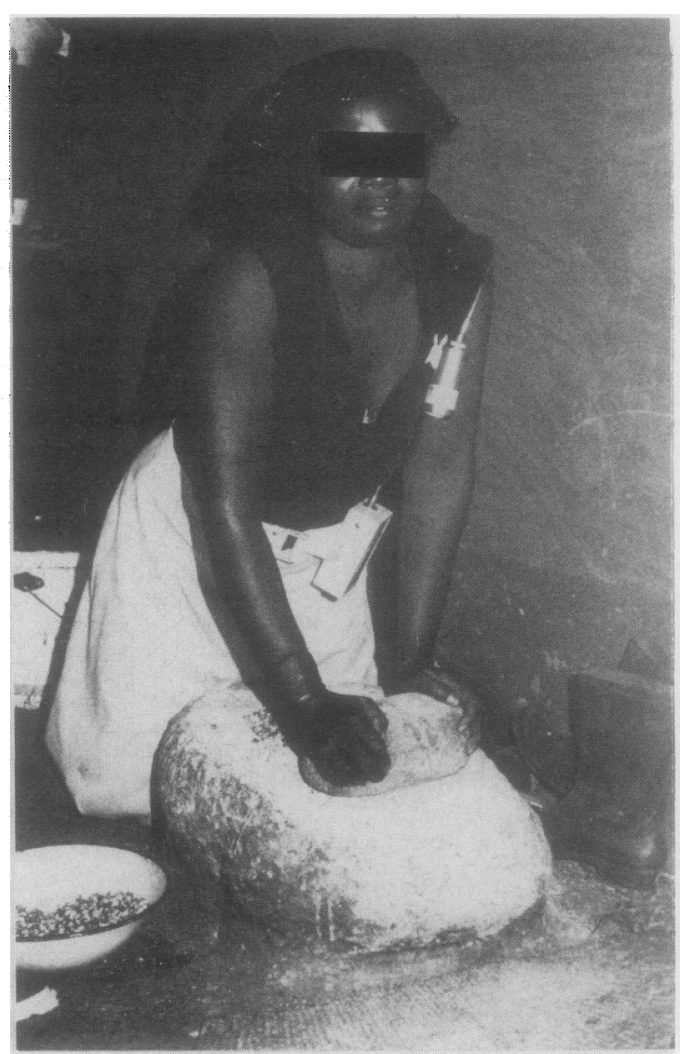

Figure 1 Transkei woman grinding maize in a poorly ventilated hut. The maize kernels (in the bowl) are ground between the oblong top rock and the large base rock. The personal dust sampler used in the study is strapped to the woman's waist and lapel. 
motor driven machinery to replace traditional methods. ${ }^{3}$

Patients with this condition are still seen commonly at Groote Schuur Hospital. We report the clinical, radiological, physiological, histological and bronchoalveolar lavage fluid abnormalities found in 25 women with this condition. As relatively few quartz particles were identified in lung sections we studied concentrations of respirable quartz dust, nonquartz containing dust, and smoke in rural Transkei houses during maize grinding and cooking.

\section{Methods}

PATIENTS

All patients entered into the study, who were investigated at the Groote Schuur Hospital respiratory clinic over 12 years, satisfied five inclusion criteria. They had to (1) be rural women (predominantly from the Transkei) who for most of their lives had been exposed to smoke from cooking fires or who had ground maize by traditional methods, or both; (2) have no history of industrial or mining exposure; (3) have radiographic changes compatible with pneumoconiosis ${ }^{4}$; (4) have lung biopsy

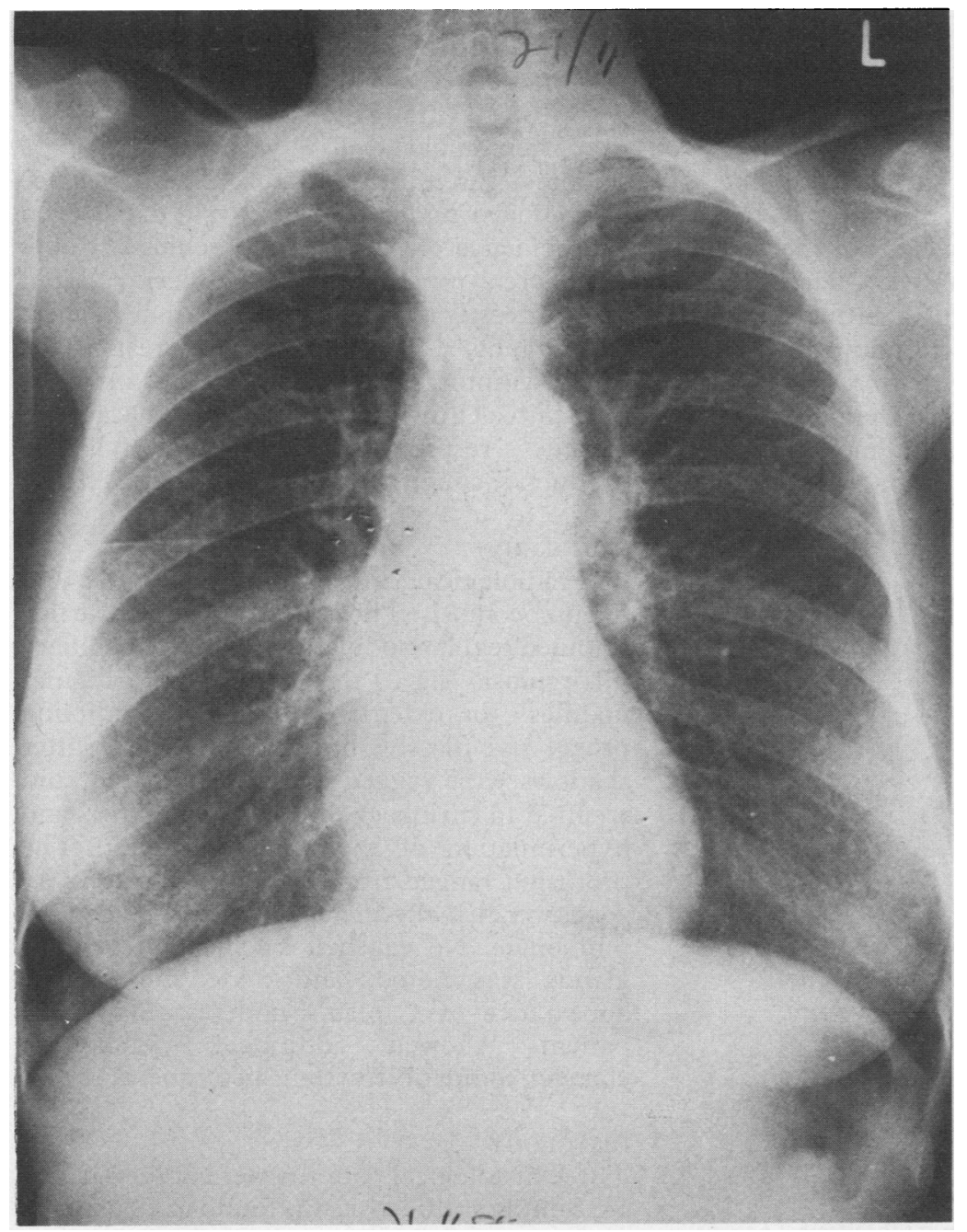

Figure 2 Chest radiograph of a 35 year old woman with hut lung showing small rounded nodules throughout both lung fields. evidence of pneumoconiosis; (5) have no bacteriological or histological evidence of active tuberculosis.

A detailed history of previous suspected or proved pulmonary tuberculosis was recorded. Chest radiographs were reviewed and compared with the UICC/ILO standard radiographs used for assessment of pneumoconioses.

\section{SPECIMENS}

Lung biopsy specimens were obtained by the transbronchial route via a fibreoptic bronchoscope from 18 patients, by drill biopsy from five patients, at open lung biopsy from one patient, and at necropsy from one patient. Haematoxylin and eosin stained lung sections were examined by conventional light microscopy and under polarised light to detect birefringent material. The latter was not quantified. Control biopsy specimens were obtained at necropsy from seven city dwelling Xhosa women (one smoker) of similar age who had died from nonpulmonary causes and who had clear lung fields on their chest radiographs. All had lived in conventional urban housing, and had not practised traditional cooking methods.

Pulmonary function tests were performed in the lung function laboratory with standard equipment and methods. Results were corrected to BTPS and expressed as a percentage of the predicted value for sex, age, height, and race..$^{5-7}$

Bronchoalveolar lavage of a peripheral lung segment was performed on eight patients during bronchoscopy and specimens of the lavage fluid were processed according to standard methods. ${ }^{8}$ All patients had conventional bacteriological investigations, including mycobacterial and fungal cultures of all bronchoscopic and other tissue specimens.

\section{STUDY OF RURAL TRANSKEI HUTS AND COOKING} METHODS

A field study of two villages (Nomonde and Tyara) in the Transkei was undertaken to examine the methods of traditional food preparation and cooking and the conditions under which it takes place. We obtained permission from women in two households in each village to monitor their daily tasks of maize grinding and cooking.

Smoke levels inside the cooking huts were measured with a Mini RAM smoke meter during cooking on an open fire fuelled with maize cobs, wood, and dried cow dung. Casella personal samplers were used to measure respirable dust concentrations during maize grinding, ${ }^{910}$ the sampler being attached to the women by means of a belt or placed on a free standing tripod $50 \mathrm{~cm}$ from the grinding rocks. Measurements were taken during grinding with sandstone and dolerite grinding rocks, as well as during the stamping of maize to produce samp ("stamp mealies"). To allow for the technical limitations of the personal samplers dust measurements were made over longer periods by arranging for the women to grind the maize for 40 minutes each in succession. 


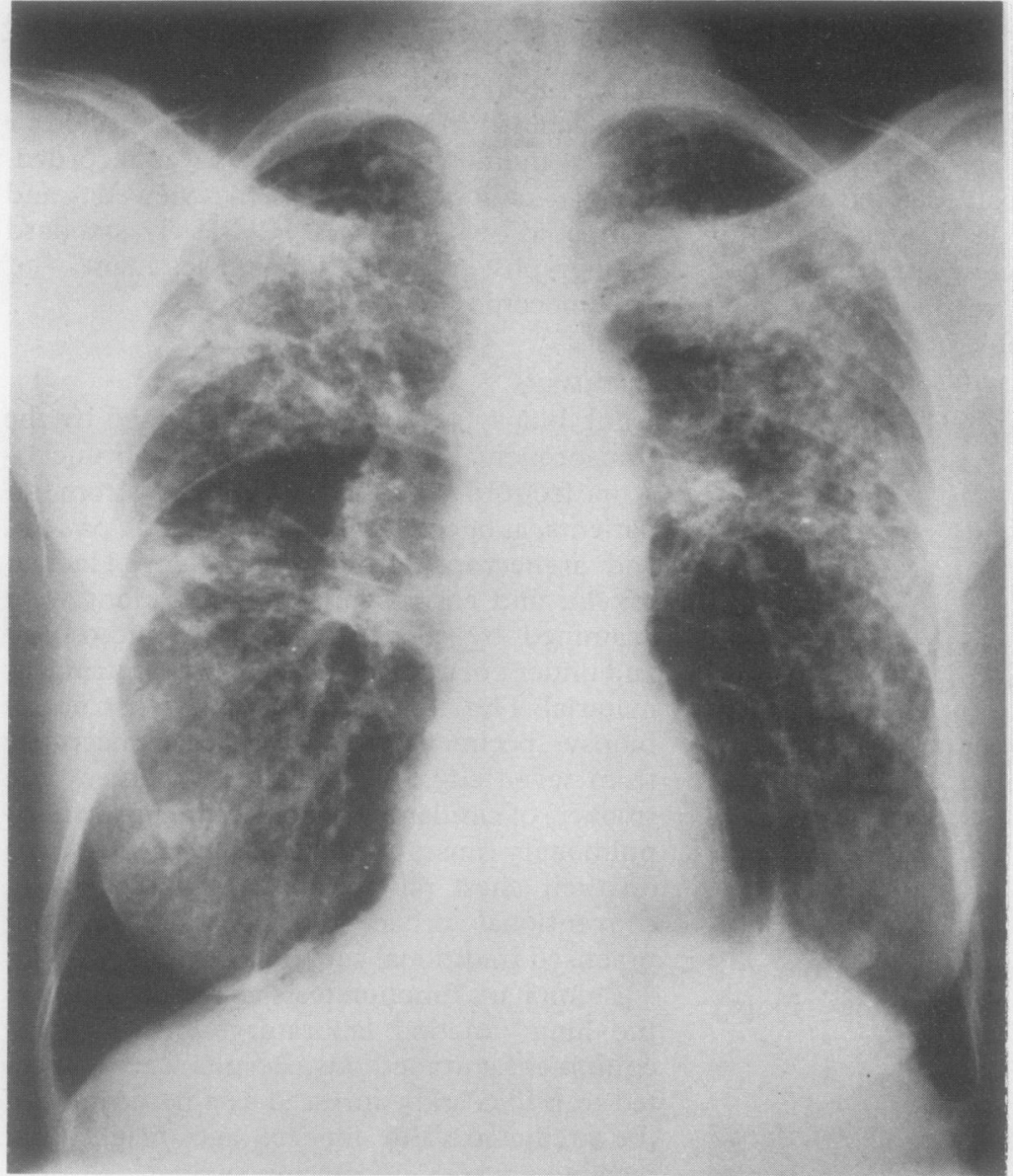

Figure 3 Chest radiograph of a 54 year old patient in this series showing progressive massive fibrosis, coalescent nodules and hyperinflation of lower lobes with bulla formation.

Respirable dust concentrations were calculated by dividing the weight of the dust by the volume of the air filtered. Quartz estimations were made by ashing the dust from the sampler filters and then determining the weight of the residual inorganic matter, shown to be quartz by $x$ ray diffraction. The percentage of quartz was calculated by dividing the weight of the quartz by the weight of the total respirable

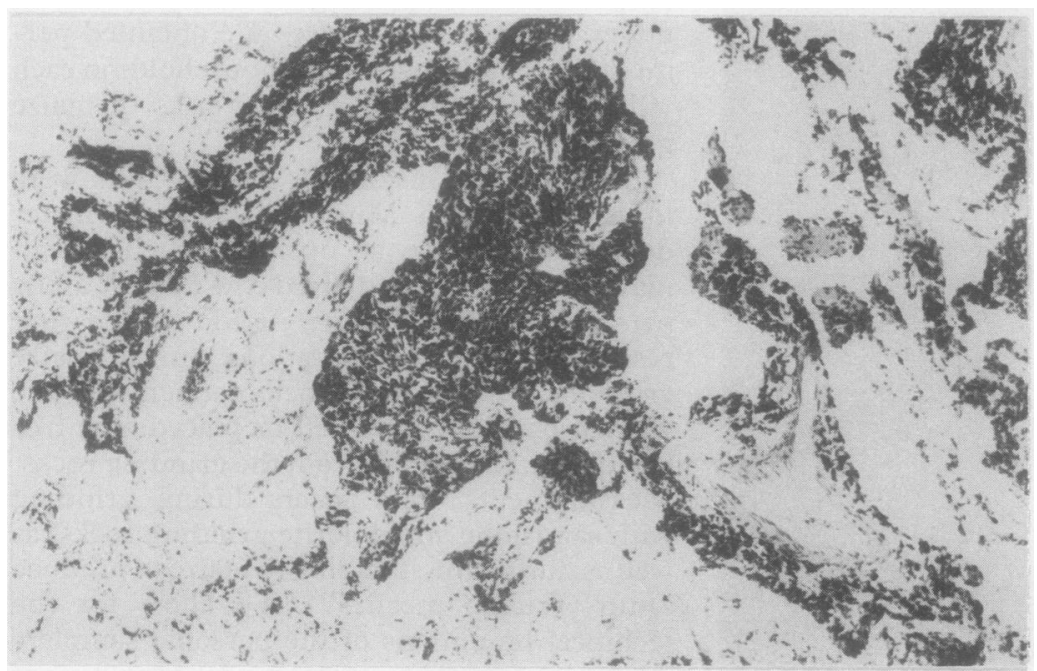

Figure 4 Photomicrograph of a section of a lung biopsy specimen taken from a patient in this series, showing anthracosis with macule formation surrounding bronchi and in the peribronchiolar interstitium. (Haematoxylin and eosin.) dust collected. The respirable quartz concentrations were then calculated by multiplying the percentage of quartz and the total respirable dust concentrations. The dust collected was also analysed by electron microscopy and $x$ ray energy spectrometry. To permit comparison with industry, the respirable dust and quartz concentrations were converted to equivalent time weighted average values of exposure for a 40 hour working week ${ }^{11}$ by dividing the values by $7 \cdot 5$ (calculated from a grinding time of $5 \cdot 25$ hours per week).

Crushed samples of two types of grinding rock were analysed by $x$ ray diffraction with a Philips goniometer. Thin sections of the same rocks were examined microscopically for texture. A sample of known pure quartz was used as a control. $X$ ray diffraction of unashed specimens of maize ground with sandstone, dolerite rock, and "stamp mealies" was performed to determine their quartz content.

\section{Results}

\section{DEMOGRAPHY}

Twenty five patients met the inclusion criteria. Twenty two were Xhosas from the Transkei. The remaining three were of mixed race from Namaqualand (on the west coast of southern Africa) and did not grind maize but were heavily exposed to domestic smoke from cooking on iron stoves fuelled by smoky wood fires in poorly ventilated huts. They met all the other inclusion criteria. The mean age of the whole group was 43 (range 20-84) years. Seventeen were non-smokers, five were tobacco pipe smokers, and three (all from Namaqualand) had smoked under 11 cigarettes a day. Seven had evidence of previous tuberculosis. Fourteen were symptomless and had been referred for investigation of abnormal chest radiographs, 13 had mild acute respiratory tract symptoms suggesting acute infective bronchitis. Only four had presented because of chronic respiratory symptoms (chronic productive cough and mild dyspnoea on effort).

\section{RADIOLOGY}

The radiological features were compatible with pneumoconiosis. They ranged from diffuse fine rounded regular nodulation resembling miliary tuberculosis (fig 2) through coarser irregular nodules to extensive fibrosis resembling progressive massive fibrosis (fig 3). The latter shadows were ragged and not lobulated, and resulted in shrinkage of the affected areas and hyperinflation of the remaining lung. The profusion ranged from $1 / 1$ to $3 / 3$ changes; all zones were usually affected. One patient had cor pulmonale. No eggshell calcification of hilar glands was noted, and none showed the appearance of Caplan's nodules. Six of 25 patients showed additional radiological changes compatible with healed tuberculosis.

\section{HISTOLOGY}

Three histological patterns were observed.

1 Simple anthracosis was found in 12 patients (defined as carbon pigment deposited within the septal and perivascular areas and surrounding 


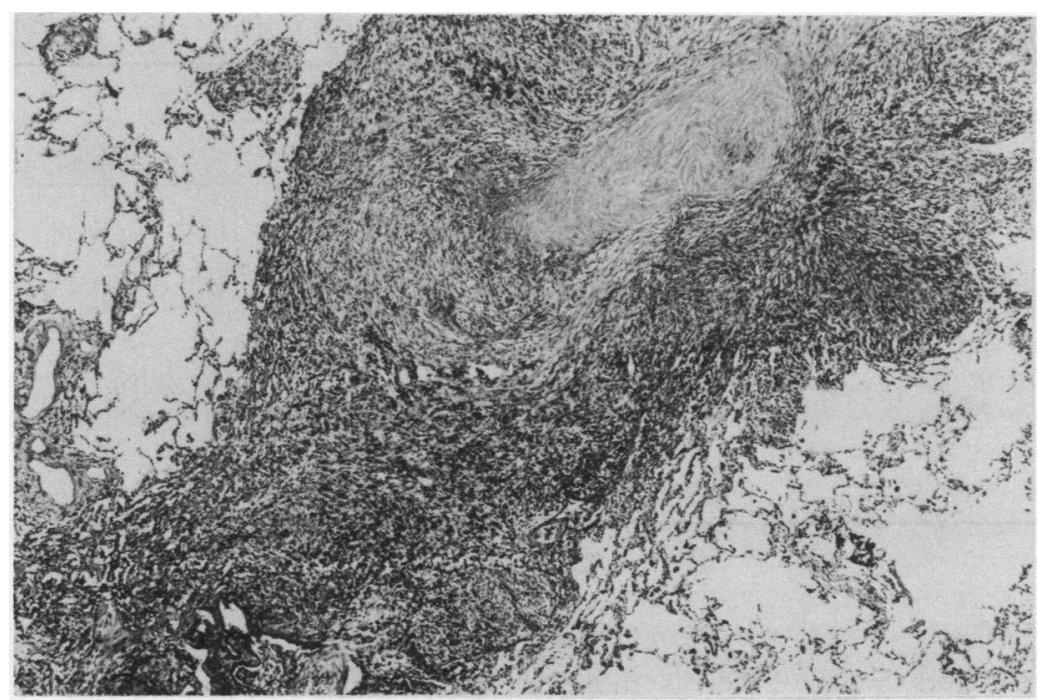

Figure 5 Photomicrograph of a section of a lung biopsy specimen taken from a patient in this series with mixed dust fibrosis. Features of a silicotic nodule are the amorphous central hyalinised tissue (on left) surrounded by a pallisade of fibroblasts.

(Haematoxylin and eosin.) irregular or stellate interstitial fibrous lesion with variable pigmentation from the inert dust, occurring predominantly in the area of the respiratory bronchiole and adjacent to small arteries. The fibrotic response ranged from small increases in reticulin to extensive collagenisation; the fibrosis extended into surrounding parenchyma in both a linear and a radial fashion in areas containing quartz. ${ }^{114}$ Doubly refractile particles were seen under polarised light, in specimens from 18 patients. ${ }^{12} 15$ None of these features was seen in the control lung biopsy specimens.

\section{LUNG FUNCTION TESTS}

Lung function measurements from 22 subjects are shown in table 1. Airflow limitation (defined as forced expiratory volume in one second $\left(\mathrm{FEV}_{1}\right)$ /forced vital capacity (FVC) below $70 \%$ or residual volume over $140 \%$ of the predicted value) was observed in 16 of the 22 patients and a restrictive pattern in one; in the remaining five patients the values were within normal limits. Carbon monoxide transfer factor (TLCO) was less than $80 \%$ of predicted in 13 of the 17 subjects tested. The mean percentage TLco was $65 \%$ (range $38-94 \%$ ). The Kco was less than $80 \%$ of the predicted value in two patients. Of the 16 patients with airflow limitation two were smokers and five had radiological evidence suggesting previous tuberculosis. None had evidence of reversible airflow limitation.

\section{BRONCHOALVEOLAR LAVAGE FLUID FEATURES}

The total cell yield was normal or mildly increased in the eight patients studied (table 2). The proportions of lymphocytes, neutrophils, and eosinophils were normal, but a large proportion of the alveolar macrophages were heavily laden with inorganic inclusions (fig 6). These were larger and more dense than those

Table 1 Results of lung function tests on 22 patients with hut lung, expressed as percentages of predicted values

\begin{tabular}{|c|c|c|c|c|c|c|c|c|}
\hline Patient no & $F E V_{1}$ & $F V C$ & $F E V_{1} / F V C$ & $T_{L C O}$ & Kco & $T L C$ & $R V$ & Smoker or $P P T B$ \\
\hline 1 & 57 & 113 & 43 & 64 & 90 & 172 & 296 & \\
\hline 2 & 66 & 119 & 47 & 54 & 68 & & & \\
\hline 3 & 52 & 61 & 76 & 38 & 88 & 105 & 273 & РPTB \\
\hline 4 & 59 & 104 & 48 & 50 & 82 & & & PPTB \\
\hline 5 & 69 & 105 & 63 & & & & & PPTB \\
\hline 6 & 111 & 143 & 67 & 94 & 121 & 159 & 244 & РPTB \\
\hline 7 & 99 & 97 & 86 & 69 & 96 & 121 & 163 & \\
\hline 8 & 105 & 97 & 91 & & & & & \\
\hline 9 & 105 & 109 & 79 & 58 & 75 & & & \\
\hline $10 \dagger$ & 112 & 111 & 79 & 72 & 88 & & & $\mathbf{S}$ \\
\hline $11 \dagger$ & 89 & 97 & 69 & 64 & 80 & 116 & 155 & \\
\hline 12 & 65 & 61 & 89 & & & 80 & 117 & S/PPTB \\
\hline 13 & 83 & 115 & 61 & 65 & 84 & 123 & 155 & \\
\hline 14 & 107 & 125 & 74 & 81 & 100 & 150 & 210 & \\
\hline 15 & 114 & 115 & 83 & 92 & 117 & & & \\
\hline 16 & 146 & 147 & 82 & 64 & 83 & 151 & 175 & \\
\hline 17 & 33 & 56 & 48 & 43 & 89 & & & РРТВ \\
\hline 18 & 55 & 64 & 74 & 53 & 115 & 95 & 149 & \\
\hline 19 & 93 & 110 & 70 & 87 & 92 & 124 & 145 & \\
\hline 20 & 62 & 75 & 61 & & & & & \\
\hline 21 & 82 & 110 & 61 & & & 169 & 275 & S/PPTB \\
\hline 22 & 87 & 134 & 63 & 66 & 91 & 188 & 218 & \\
\hline
\end{tabular}

FEV $_{1}$ - Forced expiratory volume in one second; FVC_forced vital capacity; TLco-carbon monoxide transfer factor; KcoFEV 1 - Forced expiratory volume in one second; $R$-residual volume; $S$-smoker; PPTB-probable previous tuberculosis. TLCo/litre lung volume; TLC-total lung capacity; RV-residual volume; S-smoker; PPTB-probable previous tuberculosis.
$\star$ For predicted values see ref 5 for FEV, and FVC, ref 6 for TLCo and Kco, and ref 7 for TLC and RV. There are no lung $\star$ For predicted values see ref 5 for FEV
function values for three of the 25 patients. tFrom Namaqualand. 
Table 2 Bronchoalveolar lavage fluid differential cell counts in eight patients (expressed as percentages of total inflammatory cells)

\begin{tabular}{|c|c|c|c|c|c|c|c|c|}
\hline \multirow{2}{*}{$\begin{array}{l}\text { Total cell } \\
\text { yield }\left(\times 10^{6}\right)\end{array}$} & \multirow[b]{2}{*}{ Lymphocytes (\%) } & \multirow[b]{2}{*}{ Neutrophils (\%) } & \multirow[b]{2}{*}{ Eosinophils (\%) } & \multicolumn{2}{|c|}{ Macrophages (\%) } & \multicolumn{2}{|c|}{ Giant macrophages (\%) } & \multirow[b]{2}{*}{ Smoking } \\
\hline & & & & Inclus & Clear & Inclus & Clear & \\
\hline $6 \cdot 4$ & $2 \cdot 8$ & 0.4 & $0 \cdot 4$ & $71 \cdot 5$ & $17 \cdot 3$ & $6 \cdot 6$ & $1 \cdot 0$ & $\mathbf{N}$ \\
\hline $1 \cdot 28$ & 1.9 & 0 & 0 & $80 \cdot 5$ & $11 \cdot 2$ & $5 \cdot 4$ & $1 \cdot 0$ & $\mathbf{N}$ \\
\hline $5 \cdot 28$ & $2 \cdot 3$ & 0.3 & 1.5 & $81 \cdot 0$ & $10 \cdot 6$ & $4 \cdot 3$ & 0 & $\mathrm{~N}$ \\
\hline $4 \cdot 25$ & $2 \cdot 8$ & 0 & 0.3 & $68 \cdot 0$ & $21 \cdot 6$ & 5.9 & 0.9 & $\mathbf{N}$ \\
\hline 24.95 & 1.0 & 0 & 0 & $77 \cdot 0$ & $17 \cdot 0$ & $5 \cdot 0$ & 0 & $\mathrm{~N}$ \\
\hline $15 \cdot 35$ & $1 \cdot 3$ & $6 \cdot 7$ & $1 \cdot 0$ & $61 \cdot 7$ & $25 \cdot 6$ & 3.7 & 0 & $S$ \\
\hline $31 \cdot 5$ & $7 \cdot 0$ & $7 \cdot 0$ & 0 & $56 \cdot 8$ & 18.7 & $8 \cdot 0$ & $2 \cdot 5$ & $\mathbf{N}$ \\
\hline $39 \cdot 4$ & $5 \cdot 0$ & $2 \cdot 0$ & 3.0 & $60 \cdot 0$ & $30 \cdot 0$ & 0 & 0 & $\mathrm{~N}$ \\
\hline \multicolumn{9}{|l|}{ Mean (SD) } \\
\hline $16.05(14.29)$ & $3.01(2.02)$ & $2.05(3.04)$ & $0.8(1.05)$ & $69 \cdot 6(9 \cdot 47)$ & $19 \cdot 0(6 \cdot 65)$ & $4.9(2.38)$ & $0.68(0.88)$ & \\
\hline
\end{tabular}

Inclus - with inorganic inclusions; $\mathrm{N}-$ non-smoker; $\mathrm{S}-$ smoker.

found in heavy cigarette smokers. Seven of the eight patients were non-smokers.

\section{MICROBIOLOGY}

No microbiological evidence of tuberculosis or other chronic infection was found in any patient.

FIELD STUDY AND DUST MEASUREMENTS

Women from rural Transkei cook breakfast and often the main meal of the day inside poorly ventilated huts without chimneys, on biomass fuelled fires that produce substantial smoke. Maize grinding is practised for about 45 minutes each day to produce the grain required for the staple diet of the average rural family. The process is performed by crushing dry maize kernels into a fine powder on a stable, hollowed out base rock with an oval hand held grinding rock (fig 1). A fine dust made up of particles of maize and the grinding rocks is released and inhaled by the grinder. Two rock types are used for grinding. The preferred rock is sandstone, which is soft and crumbly and composed of almost $100 \%$ quartz, and produces coarse, crunchy maize meal. The alternative rock is dolerite, which is hard wearing, contains almost no quartz, and produces finely ground maize meal. Dolerite

Figure 6 Photomicrograph of a cytocentrifuged preparation of cells obtained at bronchoalveolar lavage showing alveolar macrophages and one giant cell (in the centre) heavily laden with inorganic inclusions.

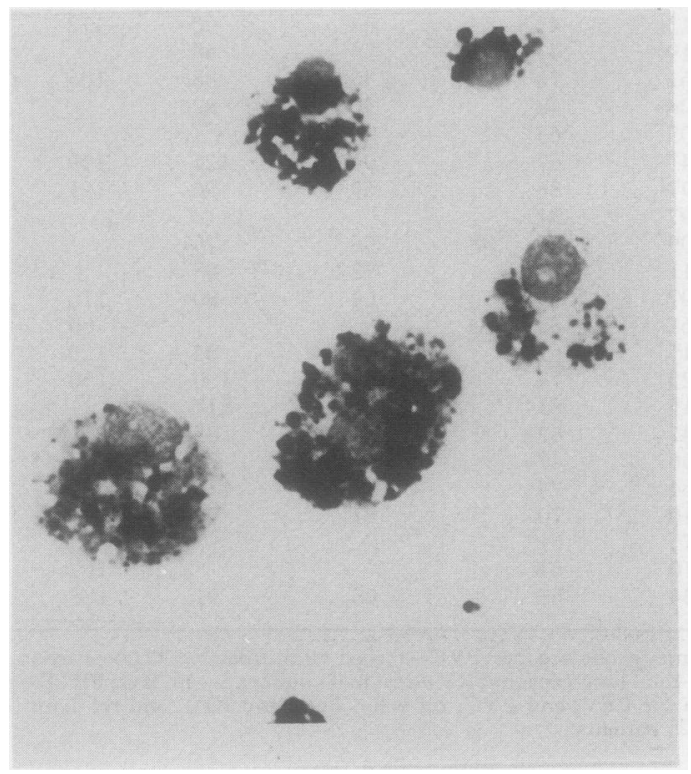

is more freely available and is used more commonly.

Maize grinding is performed by rural Xhosa women in the home after the age of about 10 years. It has been estimated that the average young woman aged 20-25 years has ground maize daily for at least eight years (with absence at school allowed for) ${ }^{1}$

The results of the measurement of respirable dust and quartz are shown in table 3. An appreciable though low concentration of respirable quartz was liberated during grinding with sandstone but not with dolerite or during stamping. The time weighted averages derived from these values are compared in table 4 with those found in a well controlled gold mine and those recommended by the United States National Institute for Occupational Safety and Health $^{16}$ and the World Health Organisation. ${ }^{17}$ The most exposed maize grinder was exposed to time weighted averages for quartz similar to those of the least exposed gold miner. These values are well within the recommended limits for time weighted averages of industrial quartz exposure. The total respirable dust concentrations during maize grinding, however, approach those of the dustiest mine activities and often exceed the recommended industrial time weighted averages.

$X$ ray diffraction of the sandstone grinding rock showed multiple quartz peaks. Thin section microscopy showed a granular, unmetamorphosed rock composed of almost $100 \%$ quartz. The pore spaces were filled with detrital material, and the rock was extensively weathered. $X$ ray diffraction of the dolerite grinding rock showed peaks corresponding to constituents of plagioclase, which is an igneous rock containing little or no free silica. Thin section microscopy showed a fine grained rock composed of $60 \%$ plagioclase, $40 \%$ augite, and less than $1 \%$ oxides. The crystalline texture was closely knit (that is, with no pore spaces), indicating a very resilient rock. No quartz was present. Analysis of maize ground with the sandstone rock confirmed multiple peaks representing quartz, whereas that ground with dolerite showed no quartz or plagioclase peaks but large numbers of low intensity peaks suggesting inorganic material. "Stamp mealies" contained neither.

Electron microscopy of dust trapped in sam- 
Table 3 Domestic respirable dust and quartz concentrations

\begin{tabular}{llllll}
\hline $\begin{array}{l}\text { Grinding } \\
\text { time (min) }\end{array}$ & $\begin{array}{l}\text { Air volume } \\
\left(\mathrm{m}^{3}\right)\end{array}$ & $\begin{array}{l}\text { Dust weight } \\
(\mathrm{mg})\end{array}$ & $\begin{array}{l}\text { Respirable dust } \\
\left(\mathrm{mg} / \mathrm{m}^{3}\right)\end{array}$ & $\begin{array}{l}\text { \% } \\
\text { quartz }\end{array}$ & $\begin{array}{l}\text { Respirable } \\
\text { quartz }\left(\mathrm{mg} / \mathrm{m}^{3}\right)\end{array}$ \\
\hline $\begin{array}{l}\text { Sandstone } \\
\text { PS 40 }\end{array}$ & 0.076 & 0.23 & 3.03 & 3.2 & 0.097 \\
SS 60 & 0.122 & 0.71 & 5.82 & 3.2 & 0.186 \\
Dolerite & & & & & \\
$\quad$ PS 158 & 0.324 & 0.85 & 2.62 & 0.9 & 0.024 \\
SS 160 & 0.288 & 0.98 & 3.40 & 0.7 & 0.024 \\
Stamping 50 & 0.098 & 0.43 & 4.39 & $<0.01$ & $<0.004$ \\
\hline
\end{tabular}

*Crushing of maize kernals with a pestle and mortar usually made of wood.

PS-personal sampler (attached to grinder); SS—-standing sampler (placed on tripod).

Table 4 Equivalent time weighted average respirable dust and quartz concentrations in maize grinders and South African gold miners, with recommended concentrations

\begin{tabular}{|c|c|c|c|}
\hline & $\begin{array}{l}\text { Respirable } \\
\text { dust }\left(\mathrm{mg} / \mathrm{m}^{3}\right)\end{array}$ & $\begin{array}{l}\% \\
\text { quartz }\end{array}$ & $\begin{array}{l}\text { Respirable } \\
\text { quartz }\left(\mathrm{mg} / \mathrm{m}^{3}\right)\end{array}$ \\
\hline MAIZE GRINDERS & & & \\
\hline $\begin{array}{l}\text { Sandstone grinder } \\
\text { PS } \\
\text { SS }\end{array}$ & $\begin{array}{l}0.404 \\
0.776\end{array}$ & $\begin{array}{l}3 \cdot 0 \\
3 \cdot 0\end{array}$ & $\begin{array}{l}0.013 \\
0.023\end{array}$ \\
\hline $\begin{array}{l}\text { Dolerite grinder } \\
\text { PS } \\
\text { SS }\end{array}$ & $\begin{array}{l}0.349 \\
0 \cdot 453\end{array}$ & $\begin{array}{l}0.9 \\
0.7\end{array}$ & $\begin{array}{l}0.0032 \\
0.0032\end{array}$ \\
\hline $\begin{array}{l}\text { GOLD MINERS } \\
\text { Rock driller } \\
\text { Blaster } \\
\text { Team leader } \\
\text { Locomotive driver }\end{array}$ & $\begin{array}{l}0 \cdot 844 \\
0 \cdot 649 \\
0 \cdot 649 \\
0 \cdot 363\end{array}$ & $\begin{array}{r}19 \cdot 0 \\
20 \cdot 0 \\
13 \cdot 0 \\
6 \cdot 0\end{array}$ & $\begin{array}{l}0 \cdot 160 \\
0 \cdot 130 \\
0 \cdot 032 \\
0.022\end{array}$ \\
\hline $\begin{array}{l}\text { RECOMMENDED CONCENTRATIONS } \dagger \\
\text { NIOSH }{ }^{16}(1975): \text { TLV-TWA } \\
\text { WHO }^{17}(1986): \text { TLV-TWA }\end{array}$ & $\begin{array}{l}0.3 \\
0.5\end{array}$ & & $\begin{array}{l}0 \cdot 10 \\
0.04\end{array}$ \\
\hline
\end{tabular}

PS, SS-see table 3 .

TLV-TWA-threshold limit value, time weighted average; NIOSH-National Institute of Occupational Safety and Health (USA); WHO-World Health Organisation.

$\star$ From unpublished work by J H Quilliam, Chamber of Mines, Johannesburg, 1978.

plers during grinding with sandstone confirmed quartz particles, dolomite $\left(\mathrm{CaMg}\left(\mathrm{CO}_{3}\right)_{2}\right)$, and complex particles consisting of aluminium, calcium, chloride, iron, magnesium, potassium, and silicone.

The average smoke concentration during cooking (table 5) far exceeded that permitted in industry.

\section{Discussion}

This study provides additional information about the nature of the domestic pneumoconiosis originally called Transkei silicosis. Although the typical patient is a rural Transkei woman exposed to domestic smoke during cooking and maize grinding, we found a similar condition in three rural Namaqua women who

Table 5 Smoke concentrations in a cooking hut at various stages of food preparation *

\begin{tabular}{lll}
\hline & $\begin{array}{l}\text { Average smoke } \\
\text { concentration }\left(\mathrm{mg} / \mathrm{m}^{3}\right)\end{array}$ & $\begin{array}{l}\text { Sampling time } \\
(\mathrm{min})\end{array}$ \\
\hline Cooking on fire made from maize cobs, wood, & & \\
and cow dung & 30.0 & 20 \\
Dry maize grinding with fire low & 7.8 & 40 \\
Fire smouldering with no domestic activity & 0.6 & 32 \\
\hline
\end{tabular}

*Huts poorly ventilated but door open; smoke concentration measured at one minute intervals. do not grind maize but have similar exposure to smoky wood fuelled stoves in poorly ventilated dwellings. We have confirmed the presence of respirable quartz in relation to maize grinding and in the ground maize of Transkeian women, but the concentrations of atmospheric respirable quartz were well below the recommended safe time weighted averages for quartz exposure. Time weighted averages are considered to be exposure levels below which disease is unlikely to occur over 35 years of work. ${ }^{11} 16$ Although sandstone grinding rocks are preferred, they are used less than dolerite, which is more widely available; grinding with dolerite liberates much less quartz. These data suggest that domestic smoke may be more important than maize grinding in causing the pneumoconiosis. Our series includes patients in their 20s, which suggests heavy dust exposure from an early age.

Histological examination of lung tissue confirmed that there were relatively few birefringent particles but many heavily anthracotic macules similar to those seen in simple coalworkers' pneumoconiosis. Birefringence is not specific and is a feature of more than 200 types of particles, of which quartz is one. Alveolar macrophages contained dense black inclusions compatible with carbon and other components of smoke.

Total respirable dust concentrations, approached those seen in the most heavily exposed gold miners, and smoke concentrations were unacceptably high. Women are exposed to smoke for longer each day than to the dust of grinding, particularly in cold weather. Airflow limitation is not a feature of early simple nodular silicosis and our finding of airflow obstruction suggests that our patients had airway disease. This is likely to be the result of smoke inhalation as it could not be attributed to tobacco smoking or previous tuberculosis. Taken together this evidence suggests that "Transkei silicosis" is a pneumoconiosis of mixed aetiology, with major contributions from "nuisance dust" of inorganic origin and smoke from biomass fuelled fires. Quartz dust appears to contribute in some patients but probably to a minor degree. Possibly certain components of the organic maize dust inhaled contribute by causing extrinsic allergic alveolitis. We therefore propose that the term "hut lung" should be used for this condition, in recognition of its mixed aetiology and occurrence in other areas of southern Africa where similar domestic conditions prevail.

The contribution of small amounts of quartz to mixed dust fibrosis caused by relatively nonfibrogenic inorganic dusts, such as carbon, iron, kaolinite, and feldspar, is well known. ${ }^{11} 18$ In this setting the fibrogenesis relates to the quartz content of the mixed dust. More detailed studies will be required to establish whether women with more severe forms of hut lung have been more exposed to respirable quartz. Another variable might be the young age at which these women are first exposed to the dust. Infants secured on the mother's back are in close proximity to the source of dust during 
grinding and food preparation. The role of previous tuberculosis also remains to be defined; several patients in this series had evidence of previous tuberculous disease. We may also speculate whether hut lung predisposes to the development of tuberculosis, as occurs with occupational silicosis. ${ }^{11}$

The range of clinical manifestations of hut lung is well illustrated by this study. Most patients have a benign form that appears to progress very slowly over many years of exposure without causing illness or disability. Most patients had no respiratory symptoms and only mild radiological and physiological abnormalities. Attention is usually drawn to their radiograph when they present with incidental acute bronchitis. Progressive massive fibrosis develops in a minority and may progress to respiratory failure with cor pulmonale and death. The degree of histological abnormality noted in this study is almost certainly an underestimate due to the limited size of the transbronchial biopsy specimens obtained at fibreoptic bronchoscopy, the method used in most of our patients. Those obtained at open lung biopsy and at necropsy were the only ones showing silicotic nodules. Given the nature of the radiological changes, larger specimens would be likely to show advanced histological changes in many more patients.

The bronchoalveolar lavage findings in hut lung have not been previously described and are of some value in distinguishing this condition from miliary tuberculosis, in which an excess of lavage fluid lymphocytes is often found. ${ }^{19}$ In hut lung a high proportion of alveolar macrophages are heavily laden with dense inorganic inclusions. Although heavy cigarette smokers have similar proportions of alveolar macrophages containing inclusions, these particles are finer than those found in hut lung.

A major clinical dilemma is distinguishing this disease from miliary tuberculosis, particularly as some patients have both conditions. Palmer and Daynes recommended that all patients with any possibility of miliary tuberculosis should be given a diagnosis of tuberculosis in the first instance and receive treatment. ${ }^{1}$ Our study suggests that fibreoptic bronchoscopy and bronchoalveolar lavage should facilitate accurate diagnosis and obviate the need for a therapeutic trial of antituberculous treatment. In a rural setting, where these patients are most commonly encountered and where facilities for fibreoptic bronchoscopy are usually not available, recognising that hut lung often presents as acute bronchitis that settles rapidly with antibiotics should help management. Inpatient assessment is essential until the results of sputum and other tests are known. Empirical treatment with antituberculous drugs is nevertheless often necessary because of the serious consequences of not treating miliary tuberculosis.

We conclude that hut lung occurs as a result of exposure to both non-quartz and quartz containing dusts as well as smoke from biomass fuelled fires. The radiological appearance is that of pneumoconiosis and histologically it ranges from simple anthracosis to progressive massive fibrosis. Airflow limitation and reduced carbon monoxide transfer factor are common and appear to be independent of the effects of smoking and previous tuberculosis. Patients are generally symptom free. A few cases progress to cor pulmonale and death. Bronchoalveolar lavage fluid, bronchial brushings, and transbronchial lung biopsy specimens may help to distinguish hut lung from miliary tuberculosis. Preventive campaigns in rural areas are needed, focusing on improved ventilation of cooking huts through the use of chimneys, general reduction of nuisance dust and exposure, and grinding with quartz free rock or preferably mechanised grinders. Such measures need to be applied in all rural communities practising similar traditional cooking methods.

We acknowledge financial assistance from the South African Medical Research Council and the University of Cape Town staff research fund. We are indebted to staff nurses $P$ Mdlatu and $N$ Nongowuza, who acted as interpreter and guide respectively; Mr R E G Rendall of the National Centre for Occupational Health, Johannesburg, for assistance with the atmospheric sampling and analysis; Dr D J G Harloe the atmospheric pathology, University of Cape Town) for reviewing the pathopathology, University of Cape Town) for reviewing the pathothe department of geology, University of Cape Town, for the department of geology, University
analysing the rock and maize samples.

1 Palmer PES, Daynes WG. Transkei silicosis. $S$ Afr Med J 1967;41:1182-8.

2 Van der Walt E, Kloppers PJ, Solleder G. Disease patterns in Transkei and Ciskei. S Afr Med J 1983;63:568-70.

3 Daynes WG. The prevention of Transkei silicosis. $S A f r$ Med J 1973;47:352-3.

4 International Labour Office. Guidelines for the use of the ILO international classification of radiography of pneumoconiosis. international classification of radiography of pneumoconiosis. Geneva: ILO,

5 Schoenberg JB, Beck GJ, Bouhuys A. Growth and decay of pulmonary function in healthy blacks and whites. Respir Physiol 1978;33:367-93.

6 Cotes JE. Lung function: assessment and application in medicine. 4th ed. Oxford: Blackwell, 1979:329-97.

7 Grimby G, Soderholm B. Static lung volumes and maximum voluntary ventilation in adults with a note on physical fitness. Acta Med Scand 1963;173:199-206.

8 Turner-Warwick ME, Haslam PL. Clinical applications of bronchoalveolar lavage: an interim view. $\mathrm{Br} J$ Dis Chest 1986;80:105-21.

9 Hamilton RJ, Walton WH. The selective sampling of respirable dusts. In: Davies $\mathrm{CN}$, ed. Inhaled particles and vapours. Oxford: Pergamon, 1961:465.

10 Orenstein AJ, ed. Proceedings of the Pneumoconiosis Conference in Johannesburg, 1959. London: Churchill, 1960 $1-29$.

11 Parkes WR. Occupational lung disorders. 2nd ed. London Butterworths, 1982:31-88, 134-232.

12 Mark EJ. Lung biopsy interpretation. Baltimore: Williams and Wilkins, 1984:14, 78-85.

13 Kleinerman J, Green F, Harley RA. Pathology standards for coal workers' pneumoconiosis. Arch Pathol Lab Med 1979; 103:375-85.

14 Katzenstein AA, Askin FB. Surgical pathology of nonneoplastic lung disease. Philadelphia: Saunders, 1982 84-5.

15 Wolman M. On the use of polarised light in pathology. Pathol Annu 1970;5:381-416.

16 National Institute for Occupational Safety and Health. Criteria for a recommended standard occupational exposure Criteria for a recommended standard occupational exposure
to crystalline silica. Washington DC: Department of to crystalline silica. Washington DC: Depart

17 World Health Organisation. Recommended Health-Based Limits in Occupational Exposure to Selected Mineral Dusts (silica, coal). Geneva: WHO, 1986:734.

18 Martin JC, Daniel-Moussard H, Le Bouffant L, Policard A. The role of quartz in the development of coal worker's pneumoconiosis. Ann NY Acad Sci 1972;200:127-41

19 Bateman ED, Ainslie GM. Bronchoalveolar lavagewindow to the lung. $S$ Afr Med J 1990;77:550-2. 